\title{
Congenital heart disease in the neonate: results of surgical treatment
}

\author{
E L BOVE, C BULL, J STARK, M DE LEVAL, F J MACARTNEY, AND J F N TAYLOR \\ Thoracic Unit, The Hospital for Sick Children, London
}

SUMMARY All 212 neonates undergoing cardiac surgery at this hospital during the 5-year period from 1976 to 1980 inclusive were reviewed. Forty required open heart surgery with $23(57 \%)$ deaths. One hundred and seventy-four neonates underwent non-bypass procedures and could be divided into three groups: group 1 (82 patients) had inadequate pulmonary blood flow, group 2 (33 patients) had increased pulmonary blood flow or inadequate mixing, and group 3 (59 patients) had coarctation of the aorta, alone or with associated lesions. Forty-four $(25 \%)$ of the neonates undergoing nonbypass procedures died. Two required bypass surgery later in the first month of life. Metabolic acidosis and the need for preoperative respiratory support were appreciably greater in non-surviving patients. The spectrum of diagnoses encountered and types of operative procedures performed are analysed.

Refinements in the surgical treatment of congenital heart disease in the neonate continue to evolve. Previous reports of cardiac surgery in the newborn have shown small numbers of patients and a high operative mortality. ${ }^{1-35-8}$ The form of treatment chosen depends on the complexity of the cardiac anomaly as well as the overall condition of the patient.

As the preliminary diagnosis and treatment of many of these critically ill infants improves, decisions regarding the timing and type of operative therapy must be made at an earlier age. We have reviewed all neonates undergoing cardiac surgery at this hospital during a consecutive 5-year period. A brief discussion of the patients during the first 4 years of the study has been presented previously. ${ }^{8}$ The spectrum of anomalies encountered, operations performed, and the preoperative condition of the patients are analysed.

\section{Patients and methods}

From January 1976 to the end of December 1980, 212 neonates underwent 224 operations on the heart and great vessels at this hospital. These operations represented $11.4 \%$ of all procedures performed here during the 5 -year period. The neonatal period is defined as the period between birth and 28 days of age. Mortality for the series implies mortality in hospital, irrespective of the time since operation. No attempt was made to include deaths occurring beyond the first hospital admission.
Bypass procedures. Forty patients underwent procedures involving cardiopulmonary bypass. Neonates constitute only $3.5 \%$ of our patients undergoing such operations as the procedures were undertaken only when both the cardiologist and surgeon caring for the patient felt that survival was unlikely without open heart surgery. Many conditions are represented in this group (Table 1). Two patients had previously undergone coarctation repair. All patients underwent operation using surface and core cooling techniques with or without total circulatory arrest. Cardioplegia was used routinely during the last 3 years of this study. ${ }^{9}$

Non-bypass procedures. One hundred and seventyfour neonates underwent non-bypass procedures (23\% of our total non-bypass procedures during this period). They can be divided into three groups according to the predominant haemodynamic problem: group 1 comprised 82 patients with inadequate pulmonary blood flow (Table 2); group 2 comprised 33 patients with increased pulmonary blood flow or inadequate mixing (Table 3 ); and group 3 comprised 59 patients with coarctation of the aorta, alone or with associated lesions (Table 4).

Seventy-two systemic to pulmonary artery shunts, either alone or with a pulmonary valvotomy were performed for patients in group 1. The BlalockTaussig shunt was our procedure of choice. Modified Blalock-Taussig shunts using Gore-Tex ${ }^{10}$ were used 
Table 1 Procedures in 40 patients using cardiopulmonary bypass

\begin{tabular}{|c|c|c|c|c|}
\hline \multirow[t]{2}{*}{ Diagnosis } & \multirow{2}{*}{$\begin{array}{l}\text { No of } \\
\text { patients }\end{array}$} & \multirow[t]{2}{*}{ Procedure } & \multicolumn{2}{|c|}{ Mortality } \\
\hline & & & No & $\%$ \\
\hline Total anomalous pulmonary venous drainage & 16 & Complete repair & 8 & 50 \\
\hline Truncus arteriosus & 6 & Complete repair & 5 & 83 \\
\hline Pulmonary stenosis* & 5 & Pulmonary valvotomy and transannular patch & 1 & 20 \\
\hline Transposition of the great arteries & 2 & Mustard & 1 & 50 \\
\hline Transposition of the great arteries & 1 & Arterial switch and tricuspid valvuloplasty & 1 & 100 \\
\hline $\begin{array}{l}\text { Transposition of the great arteries, ventricular } \\
\text { septal defect, previous coarctation }\end{array}$ & 1 & Mustard and ventricular septal defect repair & 1 & 100 \\
\hline $\begin{array}{l}\text { Ventricular septal defect, interrupted arch, } \\
\text { aortic stenosis }\end{array}$ & 1 & $\begin{array}{l}\text { Closure ventricular septal defect, ascending to } \\
\text { descending aorta conduit, valvotomy }\end{array}$ & 1 & 100 \\
\hline Ventricular septal defect, absent pulmonary valve & 1 & Closure ventricular septal defect & 1 & 100 \\
\hline Ventricular septal defect $\dagger$ & 2 & Closure ventricular septal defect & 0 & $\mathbf{0}$ \\
\hline Complete atrioventricular canal & 1 & Complete repair & 1 & 100 \\
\hline $\begin{array}{l}\text { Ventricular septal defect, common atrium, } \\
\text { anomalous systemic venous return }\end{array}$ & 1 & Closure ventricular septal defect, atrial baffle & 1 & 100 \\
\hline Aortic stenosis & 3 & Valvotomy & 2 & 67 \\
\hline
\end{tabular}

*One patient required reoperation and survived, tone patient had previously undergone coarctation repair.

Table 2 (Group I) Inadequate pulmonary blood flow (82 patients)

\begin{tabular}{|c|c|c|c|}
\hline \multirow[t]{2}{*}{ Diagnosis } & \multirow[t]{2}{*}{$\begin{array}{l}\text { No of } \\
\text { patients }\end{array}$} & \multicolumn{2}{|c|}{$\begin{array}{l}\text { Operative } \\
\text { mortality }\end{array}$} \\
\hline & & No & $\%$ \\
\hline $\begin{array}{l}\text { Pulmonary atresia/intact ventricular } \\
\text { septum }\end{array}$ & 25 & 6 & 24 \\
\hline $\begin{array}{l}\text { Pulmonary atresia/ventricular septal } \\
\text { defect }\end{array}$ & 14 & 5 & 36 \\
\hline $\begin{array}{l}\text { Univentricular heart with pulmonary } \\
\text { atresia or stenosis* }\end{array}$ & 23 & 5 & 22 \\
\hline Tetralogy of Fallot & 9 & 2 & 22 \\
\hline $\begin{array}{l}\text { Atrioventricular discordance/pulmonary } \\
\text { stenosis }\end{array}$ & 3 & 0 & 一 \\
\hline $\begin{array}{l}\text { Double outlet right ventricle/pulmonary } \\
\text { atresia }\end{array}$ & 1 & 0 & 一 \\
\hline Critical pulmonary stenosis & 3 & 0 & 一 \\
\hline Ebstein's anomaly/pulmonary atresia & 1 & $\mathbf{0}$ & - \\
\hline $\begin{array}{l}\text { Transposition of great arteries/ventricular } \\
\text { septal defect/pulmonary stenosis }\end{array}$ & 1 & 0 & 一 \\
\hline $\begin{array}{l}\text { Complete atrioventricular } \\
\text { canal/pulmonary atresia/total } \\
\text { anomalous pulmonary venous } \\
\text { drainage }\end{array}$ & 2 & 1 & 50 \\
\hline
\end{tabular}

*Includes tricuspid atresia.

if anatomical conditions precluded the standard shunt or if shunts were performed on the side of the aortic arch, as when combined with transpulmonary valvotomy for pulmonary atresia with intact ventricular septum.

The procedures performed to decrease pulmonary blood flow or improve mixing in group 2 included ligation of persistent ductus arteriosus (17 patients), or pulmonary artery banding either alone (8 patients), or in addition to Blalock-Hanlon septectomy (3 patients). Two patients with pulmonary atresia, ventricular septal defect, and a multifocal pulmonary blood supply required ligation of aorto-pulmonary collateral arteries.

The procedures used to repair the coarctation in
Table 3 (Group 2) Increased pulmonary blood flow/inadequate mixing (33 patients)

\begin{tabular}{|c|c|c|c|}
\hline \multirow[t]{2}{*}{ Diagnosis } & \multirow{2}{*}{$\begin{array}{l}\text { No of } \\
\text { patients }\end{array}$} & \multicolumn{2}{|c|}{ Mortality } \\
\hline & & No & $\%$ \\
\hline Persistent ductus arteriosus isolated & 7 & $\mathbf{0}$ & - \\
\hline $\begin{array}{l}\text { Ventricular septal defect/persistent } \\
\text { ductus arteriosus }\end{array}$ & 9 & 2 & 22 \\
\hline Transposition of the great arteries & 2 & 0 & - \\
\hline $\begin{array}{l}\text { Transposition of the great } \\
\text { arteries/persistent ductus arteriosus }\end{array}$ & 4 & 1 & 25 \\
\hline $\begin{array}{l}\text { Double outlet right ventricle/persistent } \\
\text { ductus arteriosus }\end{array}$ & 2 & $\mathbf{0}$ & 一 \\
\hline $\begin{array}{l}\text { Ventricular septal defect/interrupted } \\
\text { arch/persistent ductus arteriosus }\end{array}$ & 1 & 1 & 100 \\
\hline $\begin{array}{l}\text { Complete atrioventricular } \\
\text { canal/persistent ductus arteriosus }\end{array}$ & 1 & 1 & 100 \\
\hline $\begin{array}{l}\text { Univentricular heart/persistent ductus } \\
\text { arteriosus }\end{array}$ & 3 & 1 & 33 \\
\hline Truncus arteriosus & 1 & 1 & 100 \\
\hline $\begin{array}{l}\text { Aortic stenosis/mitral } \\
\text { stenosis/endocardial } \\
\text { fibroelastosis/persistent ductus } \\
\text { arteriosus }\end{array}$ & 1 & 1 & 100 \\
\hline $\begin{array}{l}\text { Pulmonary atresia/ventricular septal } \\
\text { defect/multiple aortopulmonary } \\
\text { collateral arteries }\end{array}$ & 2 & 0 & - \\
\hline
\end{tabular}

Table 4 (Group 3) Coarctation syndrome (59 patients)

\begin{tabular}{|c|c|c|c|}
\hline \multirow[t]{2}{*}{ Diagnosis } & \multirow[t]{2}{*}{$\begin{array}{l}\text { No of } \\
\text { patients }\end{array}$} & \multicolumn{2}{|c|}{$\begin{array}{l}\text { Operative } \\
\text { mortality }\end{array}$} \\
\hline & & No & $\%$ \\
\hline Isolated coarctation & 28 & 3 & 11 \\
\hline \multicolumn{4}{|l|}{ Complex coarctation } \\
\hline With ventricular septal defect* & 22 & 7 & 32 \\
\hline With other $\dagger$ & 7 & 5 & 71 \\
\hline $\begin{array}{l}\text { Interrupted aortic arch with } \\
\text { ventricular septal defect }\end{array}$ & 1 & 1 & 100 \\
\hline $\begin{array}{l}\text { Aortic valve stenosis (valvotomy } \\
\text { on inflow occlusion) }\end{array}$ & 1 & 10 & 100 \\
\hline
\end{tabular}

*Three patients also had pulmonary artery banding, with one death. †Tuncus arteriosus, transposition of the great arteries/ventricular septal defect, complete atrioventricular canal, univentricular heart, double outlet right ventricle; one patient also had pulmonary artery banding with death. 
group 3 patients included subclavian flap angioplasty, aortic resection with end-to-end anastomosis, patch angioplasty and, in one case, carotid artery to descending aorta anastomosis. Subclavian flap angioplasty became our procedure of choice for this age group during the latter part of the period.

Preoperative risk factors. The following risk factors in the preoperative condition of these patients were analysed retrospectively: weight, the need for respiratory support (ventilation or continuous positive airways pressure), seizures, cardiac arrest with successful resuscitation, renal failure, and significant complication at the time of cardiac catheterisation. Renal failure was defined as occurring in any patient who received preoperative peritoneal dialysis or was anuric for at least 12 hours before operation. Complications of catheterisation included intramyocardial injection of contrast material or intrapericardial haemorrhage with or without tamponade.

Contingency tables were analysed using the $\chi^{2}$ test for goodness of fit or the log maximum likelihood estimator function when sample size was small. The difference between two means was determined using the Student's $t$ test for independent means. Multivariate risk analysis was not carried out because of the paucity of risk factors identified on univariate analysis and because many risk factors occurred in so few patients. Moreover, a matrix of diagnoses against operations would, in many cases, have contained only one or two patients per cell.

\section{Results}

Cardiopulmonary bypass procedures. Among the 40 patients undergoing procedures requiring cardiopulmonary bypass, $23(57 \%)$ died. The mortality rate for each diagnostic group is shown in Table 1. Several neonates who did not survive were moribund preoperatively. For example, one neonate who underwent complete repair of persistent truncus arteriosus had generalised seizures, renal failure, and disseminated intravascular coagulopathy before the operation. Another child with infradiaphragmatic total anomalous pulmonary venous drainage had agenesis of the left lung. Both neonates who died after closure of ventricular septal defects had complex associated lesions: one had an absent pulmonary valve and was in respiratory failure, and the other was 3 days old with additional aortic stenosis, an interrupted aortic arch, and severe congestive heart failure and acidosis. One patient undergoing arterial switch repair for transposition of the great arteries underwent urgent operation at age 3 days after balloon atrial septostomy performed at another institution inadvertently damaged the tricuspid valve.

Non-bypass procedures. The overall mortality for the 174 neonates undergoing non-bypass surgery on the heart and great vessels was $25 \%$ (44 patients). Among group 1 patients with inadequate pulmonary blood flow, 19 of 82 patients died. Most (68 patients) of these had systemic/pulmonary shunts. The remaining patients underwent pulmonary valvotomy, formalin infiltration of the ductus, or both. When analysed according to operation, the highest mortality rate was in the group of patients having a formalin infiltration of the ductus. Early in our experience, we felt that this was an adequate procedure by itself and additional shunts were not routinely performed. The mortality rate $(45 \%, 5$ of 11 patients) in our series was unacceptably high and we no longer consider this operation to be appropriate. ${ }^{11}$ Among the diagnostic categories, the patients with pulmonary atresia and ventricular septal defect showed a mortality disproportionately high $(36 \%)$ even for this group. In retrospect, some of these patients had only a few lung segments connected to the main pulmonary artery and should perhaps have been considered inoperable.

Closed pulmonary valvotomy was performed only three times as an isolated procedure and only in the rare patient with pulmonary atresia or stenosis with an intact ventricular septum who had a large, well functioning right ventricular chamber. None of these patients died. Otherwise valvotomy was combined with a systemic to pulmonary shunt or formalin infiltration of the ductus. Of the 55 classical or modified Blalock-Taussig operations performed, $8(15 \%)$ patients died. There was no difference in mortality between the standard Blalock-Taussig anastomosis and the modified Blalock-Taussig shunts performed with Gore-Tex. Although they tended as a group to have the smallest pulmonary arteries, 5 of 15 patients undergoing Waterston anastomosis died, and we now use the Waterston shunt less often.

Among the 33 patients undergoing procedures designed to decrease pulmonary blood flow or improve mixing, $8(24 \%)$ patients died including 4 patients undergoing only ligation of a persistent ductus arteriosus. These deaths occurred in patients with complex associated anomalies; there was no mortality for ligation of an isolated ductus arteriosus (7 neonates). Other patients in this group underwent pulmonary artery banding either alone (8 patients, 2 deaths) or with a Blalock-Hanlon atrial septectomy (3 patients, 1 death). Three patients had a BlalockHanlon septectomy only; in 2 patients the procedure was performed on neonates with simple transposition 
Table 5 Preoperative risk factors

\begin{tabular}{|c|c|c|c|c|}
\hline & All patients & Survivors & Non-survivors & $P$ value \\
\hline $\begin{array}{l}\text { pH } \\
\text { Respiratory support }(\%) \\
\text { Weight }(\mathrm{kg}) \\
\text { Seizures }(\%) \\
\text { Cardiac arrest }(\%) \\
\text { Renal failure }(\%) \\
\mathrm{PO}_{2}<20(\%)\end{array}$ & $\begin{array}{c}7 \cdot 32 \pm 0 \cdot 01 \\
31 \text { ( } 58 \text { patients) } \\
3 \cdot 1 \pm 0 \cdot 05 \\
3 \text { (6 patients) } \\
4 \text { (8 patients) } \\
1 \text { (2 patients) } \\
8 \text { (15 patients) }\end{array}$ & $\begin{array}{l}7 \cdot 34 \pm 0.01 \\
23 \text { (29 patients) } \\
3 \cdot 17 \pm 0.07 \\
4 \text { (5 patients) } \\
3 \text { (4 patients) } \\
0 \text { (0 patients) } \\
9 \text { (12 patients) }\end{array}$ & $\begin{array}{l}7 \cdot 29 \pm 0.02 \\
48 \text { (29 patients) } \\
2 \cdot 98 \pm 0.07 \\
2 \text { (1 patient) } \\
7 \text { (4 patients) } \\
8 \text { (2 patients) } \\
5 \text { (3 patients) }\end{array}$ & $\begin{array}{l}0.02 \\
0.01 \\
\text { NS } \\
\text { NS } \\
\text { NS } \\
\text { NS } \\
\text { NS }\end{array}$ \\
\hline
\end{tabular}

of the great arteries in whom inadequate mixing persisted despite balloon atrial septostomy. Both patients underwent surgical septectomy in preference to an interatrial repair on bypass (Table 1) because of the serious overall condition of each: septicaemia in one patient and staphylococcal pneumonia in the other. Both survived operation.

Fifteen of 57 patients undergoing repair of coarctation of the aorta died. The mortality for isolated coarctation of the aorta was $11 \%$ ( 3 of 28 patients). One neonate was moribund preoperatively, and died 2 days after surgery while undergoing peritoneal dialysis. Both the others had severely hypoplastic third parts of the aortic arch so that left ventricular obstruction was incompletely relieved. Coarctation of the aorta associated with ventricular septal defect and requiring operation in the first months of life carried a $32 \%$ mortality; coarctation associated with other more complex lesions carried a $71 \%$ mortality (Table 4 ). When the mortality was examined with respect to the type of coarctation repair, no significant differences were found with any operative approach. Since 1977 subclavian flap angioplasty has been our procedure of choice.

Preoperative risk factors. Data on possible preoperative risk factors are given in Table 5. The arterial $\mathrm{pH}$ on arrival in the unit ranged from 6.72 to 7.60 and was appreciably lower among non-surviving patients. This usually represented a metabolic acidosis. Severe respiratory distress, reflected in a need for preoperative ventilatory support, was the only other risk factor documented; the incidences of preoperative seizures, cardiac arrest, renal failure, and complications from cardiac catheterisation were all fairly low and none was shown on its own to increase mortality significantly.

\section{Discussion}

With improved methods of perinatal care, newborn resuscitation, and diagnosis, many neonates with congenital heart disease survive to require medical and operative therapy. The cardiac surgery performed on infants within the first month of life
Table 6 Neonates undergoing cardiac catheterisation in 1979 at The Hospital for Sick Children

\begin{tabular}{lcr}
\hline & $\begin{array}{l}\text { No of } \\
\text { patients }\end{array}$ & $\%$ \\
\hline Admitted & 180 & 100 \\
Catheterised & 156 & 86 \\
Operated & 54 & 30 \\
Rashkind-transposition of the & 26 & 14 \\
$\quad$ great arteries & 14 & 7 \\
Hypoplastic left heart & 12 & 6 \\
Other inoperable & 8 & 4 \\
Non cardiac disease & 3 & 1 \\
Myocarditis & 3 & 1 \\
Postoperative recatheterisation & 36 & 20 \\
Surgery delayed & & \\
\hline
\end{tabular}

represented a small percentage of all cardiac operations during the period $1976-80$ at our unit. It is particularly in this select group of patients however, that an accurate effective treatment plan must be conceived. Although congenital heart disease is commonly recognised in the first month of life, only a few patients require operation. Of 180 patients admitted in the first month of life during the calendar year 1979 at this hospital, 156 underwent cardiac catheterisation and only 54 came to operation (Table 6). With the advent of two-dimensional echocardiography many such patients are no longer even catheterised. The proportion of patients referred with non-cardiac disease and the proportion of patients admitted who required surgery as neonates are broadly comparable with those presented in a recent review of all neonatal admissions to Royal Liverpool Children's Hospital (1976-78). ${ }^{4}$ Of their total of 322 patients admitted 143 were operated on, of whom only $66(20 \%)$ underwent surgery as neonates.

The decision regarding the choice of procedure is often based on the mortality and morbidity of palliation versus complete repair in the neonate. For some patients there is no choice to be made; early correction is the only appropriate treatment for obstructed total anomalous pulmonary venous drainage ${ }^{1213}$ while solely palliation is currently available for neonates with tricuspid atresia. ${ }^{14}$ If a choice is available, the trend towards early correction 
rather than initial palliation corresponds with an increase in confidence both in the techniques of intracardiac repair and the management of cardiopulmonary bypass in infants. ${ }^{15-20}$ The strategy of early correction has been justified by studies of surgical results for several particular lesions-such as ventricular septal defect, transposition of the great arteries, and truncus arteriosus. ${ }^{21-23}$ Such patients now undergo complete repair in the neonatal period, should their cardiac condition demand operation. Debate exists over the best strategy for management of some lesions particularly those for which mortality in our hands has been disappointing (for example, coarctation with ventricular septal defect). ${ }^{\mathbf{2 4}}$

Although this study did not attempt to evaluate long-term results of treatment in early infancy, the establishment of treatment policies for the very complex problems encountered must take long-term results into consideration. ${ }^{25}$ Further studies are needed to clarify guidelines regarding the type and timing of surgical treatment and the identification of any diagnoses or preoperative conditions which would alter the type of operative conditions which would alter the type of operative intervention or dictate that any intervention is unwise. We were unable to identify a subset of patients whose cardiac defect is, when viewed in isolation, correctable, and yet whose associated risk factors add up to such a high probability of death or permanent disability that operation is contraindicated. Thus we continue to offer surgical treatment even to gravely ill neonates with complex lesions.

\section{References}

1 Lindesmith G G, Gallaher M E, Durnin R E, Meyer B W, Jones J C. Cardiac surgery in the first month of life. Ann Thorac Surg 1966; 2: 250-71.

2 Stark J, Hucin B, Aberdeen E, Waterston D J. Cardiac surgery in the first year of life: experience with 1,049 operations. Surgery 1971 ; 69: 483-97.

3 Cooley D A, Hallman G L. Surgery during the first year of life for cardiovascular anomalies. $J$ Cardiovasc Surg $1971 ; 5: 584$.

4 Dickinson D F, Arnold R, Wilkinson J L. Outcome of treatment for neonates referred to a supraregional cardiac centre 1976-78. Arch Dis Child 1982; 57: 328-33.

5 Sloan H, Mackenzie J, Morris J D, Stern A, Sigmann J. Open heart surgery in infancy. $J$ Thorac Cardiovasc Surg $1962 ; 44: 459-76$

6 Sugimura S, Starr A. Cardiopulmonary bypass in infants under four months of age. J Thorac Cardiovasc Surg 1977; 73: 894-8.

7 Pooley R W, Hayes C J, Edie R N, Gersony W M, Bowman F O, Malm $J$ R. Open heart experience in infants using normothermia and deep hypothermia. Ann Thorac Surg 1976; 22: 415-23.

8 Stark J, Bull C, Bove E. Cardiac surgery in the neonate. In: Godman M, ed. Paediatric cardiology. Vol. 4. London: Churchill Livingstone, $1981: 275-80$.

9 Bull C, Stark J. Cardioplegia in pediatric cardiac surgery-repair in the first year of life. In: Engelman R M,
Levitsky S, eds. A handbook of clinical cardioplegia. New York: Futura, 1982: 349-62.

10 de Leval M R, McKay R, Jones M, Stark J, Macartney F J. Modified Blalock-Taussig shunt. Use of subclavian artery orifice as flow regulator in prosthetic systemicpulmonary artery shunts. J Thorac Cardiovasc Surg $1981 ; 81$ : 112-9.

11 Deanfield J E, Rees P G, Bull C M. et al. Formalin infiltration of ductus arteriosus in cyanotic congenital heart disease. Br Heart J 1981 ; 45: 573-6.

12 Bove E L, de Leval M R, Taylor J F N, Macartney F J, Szarnicki $\mathbf{R}$ J, Stark J. Infradiaphragmatic tota anomalous pulmonary venous drainage. Surgical treatment and longterm results. Ann Thorac Surg 1981; 31: 544-50.

13 Katz N M, Kirklin J W, Pacifico A D. Concepts and practices in surgery for total anomalous pulmonary venous connection. Ann Thorac Surg 1978; 25: 479-87.

14 Turley K, Tucker W Y, Ebert P A. The changing role of palliative procedures in the treatment of infants with congenital heart disease. J Thorac Cardiovasc Surg 1980; 79: 194-201

15 Barratt-Boyes B G, Simpson M, Neutze J M. Intracardiac surgery in neonates and infants using deep hypothermia with surface cooling and limited cardiopulmonary bypass. Circulation 1971; 43: Supplement 1, 25-30.

16 Castenada A, Lamberti J, Sade R M, Williams R G, Nadas A S. Open-heart surgery during the first three months of life. J Thorac Cardiovasc Surg 1974; 68: 719-31.

17 Venugopal P, Olszowka J, Wagner H, Vlad P, Lambert E, Subramanian S. Early correction of congenital heart disease with surface-induced deep hypothermia and circulatory arrest. J Thorac Cardiovasc Surg 1973; 66: 375-86.

18 Bailey L L, Takeuchi Y, Williams W G, Trusler G A, Mustard W T. Surgical management of congenital cardiovascular anomalies with the use of profound hypothermia and circulatory arrest. Analysis of 180 consecutive cases. J Thorac Cardiovasc Surg 1976; 71: 485-92.

19 Bove E L, Behrendt D M. Open heart surgery in the first week of life. Ann Thorac Surg 1980; 29: 130-4.

20 Stark J. Debate on congenital heart disease. Pro: early total repair is preferable to palliative surgery in congenital heart disease. Adv Cardiol 1976; 17: 51-72.

21 McNicholas K, de Leval M, Stark J, Taylor J F N, Macartney F J. Surgical treatment of ventricular septal defect in infancy. Primary repair versus banding of the pulmonary artery and later repair. Br Heart $J$ 1979; 41: 133-8.

22 Egloff L P, Freed M D, Dick M, Norwood W I, Castenada A R. Early and late results with the Mustard operation in infancy. Ann Thorac Surg 1978; 26: 474-84.

23 Ebert $\mathbf{P} A$, Robinson $\mathbf{S}$ J, Stanger $\mathbf{P}$, Engle $\mathbf{M}$ A. Pulmonary artery conduits in infants younger than six months of age. $J$ Thorac Cardiovasc Surg 1976; 72: 351-6.

24 Leanage $R$, Taylor J F N, de Leval M R, Stark J, Macartney F J. Surgical management of coarctation of aorta with ventricular septal defect. Multivariate analysis. Br Heart J 1981 ; 46: 269-77.

25 Macartney F J, Taylor J F N, Graham G R, de Leval M R, Stark $J$. The fate of survivors of cardiac surgery in infancy. Circulation 1980; 62: 80-90.

Correspondence to J Stark FRCS, Thoracic Unit, The Hospital for Sick Children, Great Ormond Street, London WC1N 3JH.

Received 17 November 1982 